\title{
Analysis of Blocking Middle Seat Policy of Delta Airline
}

\author{
Xiaoyu $\mathrm{Li}^{1}$ \\ ${ }^{1}$ Beijing Haidian Foreign Language Experiment School, Beijing, China
}

\begin{abstract}
The main content of the research is about the seat blocking policy of Delta airline and its influences. The idea of the research comes up as airline industry is one of the most influenced industry by covid-19 pandemic and Delta's action in this severe situation is worth to analyze. SWOT analysis will be conducted in this research, force field analysis, final account analysis and ratio analysis to study the decision of empty the middle seat. From the research, the author wants to have the conclusion about how the policy is going to affect the delta airline, and whether the policy should be kept or not. The conclusion is that Delta airline should keep on the blocking seat policy because almost the passengers has good impressions on the company.
\end{abstract}

\section{INTRODUCTION}

Delta Air Lines is one of the biggest airline companies in America with its daily flight over 5,400 and it serves for 325 destinations all over the world. It is the second world largest airlines, which also takes place in the top fortune 500 list. Suddenly, the covid-19 pandemic has brought to devastate influence to airline industry. As one of the biggest airline company, Delta Air Lines have gained reputation from a series of disinfection methods, including cleaning crews, sanitizing wipe, and opening middle line. Delta Air Lines planned to keep blocking the middle line of seat in order to keep the social distance. However, recently, the Delta Air Lines lost 100 millions a day at the beginning of the pandemic and burned 27 million a day [2]. The CEO mentioned that they would not stop the seat blocking policy by the bottom of September, which shows the number of customers are going to stay in low, it will have totally different financial and strategic effect for the company. The financial situation of Delta is not preferable, and whether could the blocking middle line policy is able carry to exestuation becomes a problem.

\section{Methodology}

The SWOT analysis is one of the business analytic tool that could help to assess the effect of the external factors at present time. The SWOT stands for strength, weakness, opportunity, and threat. Strength is the internal factor that could reveal the advantage that company could gain, while the weakness is the internal factors that could reveal the organization's bad performance from the decision. Opportunity is the well external effect of certain decision, while threat is the bad external effect of the decision. This tool is a quantitative business analytic tool which could

$\overline{\text { tracylixiaoyu@qq.com }}$ give good picture of the planning process of the business [4].

The force field analysis was designed by German American psychologist Kurt Lewin, which was not only regarded as a plan but also a decision-making framework to examine the factors, against the change as well. The factors supporting the change that towards a goal which should be called driving forces, whereas those block or hinder the change are called restraining force. The final accounts compromise of the profit and the loss account of the balance sheet the cash flow statement. Both of them are important because they show the directors, owners, and other stakeholder groups as well as the financial business performance during the accounting period of time. In this kind of report, the ratio analysis is also a financial management which is commonly applied to analyze and judge the business performance [4].

\section{ANALYSIS AND DISCUSSION}

\subsection{SWOT analysis}

The SWOT analysis of the seat blocking policy will analyze the strength, weakness, opportunity, and the threat of the decision. Those are the five key points. Firstly, the strength is that the social distance kept on the plane is going to maximize the passenger securities, which is as important as our life. It can also protect the company from being sued by the almost the passengers. This action will increase the reputation of the business to the airline industry. Secondly, the passenger would trust Delta more than others, leading them to choose the flight in delta during the pandemic covid-19 and increase the customer loyalty as well. However, the decision of course has weaknesses. By limiting the number of customers on the airplane, Delta also limited its chance to increase the revenue. Delta have already lost $91 \%$ of its revenue from 
the pandemic, which stopped them from covering the loss back even they tried many times through various ways [2] In other words, people who never use Delta Air Lines will trust Delta Air Lines more, which may increase the customer base after the pandemic this year. At the same time, the threat of limiting the seat is that Delta may need a long of time to recover from the loss finally.

\subsection{Final account analysis}

The following table is the quarterly income statement of Delta Air Lines, which shows the net profit or loss, after all costs have been deduced form the organization's revenue, per quarter.

TABLE 1. INCOME STATEMENT OF DELTA AIRLINES [1]

\begin{tabular}{|c|c|c|c|c|c|}
\hline Fiscal year is January-December. All values USD Millions. & 30-Jun-2020 & 31-Mar-2020 & 31-Dec-2019 & 30-Sep-2019 & 30-Jun-2019 \\
\hline Sales/Revenue & 1,468 & 8,592 & 11,438 & 12,560 & 12,536 \\
\hline Sales Growth & $-82.91 \%$ & $-24.88 \%$ & $-8.93 \%$ & $0.19 \%$ & . \\
\hline Cost of Goods Sold (COGS) incl. D\&A & 4,800 & 8,349 & 9,061 & 9,505 & 9,476 \\
\hline COGS excluding D\&A & 4,209 & 7,671 & 8,439 & 8,874 & 8,763 \\
\hline Depreciation \& Amortization Expense & 591 & 678 & 622 & 631 & 713 \\
\hline COGS Growth & $-42.51 \%$ & $-7.86 \%$ & $-4.67 \%$ & $0.31 \%$ & . \\
\hline Gross Income & $(3,332)$ & 243 & 2,377 & 3,055 & 3,060 \\
\hline Gross Income Growth & $-1471.19 \%$ & $-89.78 \%$ & $-22.19 \%$ & $-0.16 \%$ & . \\
\hline Gross Profit Margin & $22.17 \%$ & - & - & - & - \\
\hline SG\&A Expense & 45 & 358 & 488 & 539 & 538 \\
\hline Other SG\&A & - & 358 & 488 & 539 & 538 \\
\hline SGA Growth & $-87.43 \%$ & $-26.64 \%$ & $-9.46 \%$ & $0.19 \%$ & - \\
\hline Other Operating Expense & 196 & 511 & 455 & 476 & 413 \\
\hline Unusual Expense & 3,307 & (235) & 51 & 4 & 63 \\
\hline Non Operating Income/Expense & 60 & (137) & 86 & (19) & (64) \\
\hline Interest Expense & 194 & 79 & 72 & 70 & 75 \\
\hline Interest Expense Growth & $145.57 \%$ & $9.72 \%$ & $2.86 \%$ & $-6.67 \%$ & - \\
\hline Gross Interest Expense & 194 & 79 & 72 & 70 & 75 \\
\hline Pretax Income & $(7,014)$ & (607) & 1,397 & 1,947 & 1,907 \\
\hline Pretax Income Growth & $-1055.52 \%$ & $-143.45 \%$ & $-28.25 \%$ & $2.10 \%$ & - \\
\hline Pretax Margin & $13.19 \%$ & - & - & - & - \\
\hline Income Tax & $(1,297)$ & (73) & 298 & 452 & 464 \\
\hline Consolidated Net Income & $(5,717)$ & (534) & 1,099 & 1,495 & 1,443 \\
\hline Net Income & $(5,717)$ & (534) & 1,099 & 1,495 & 1,443 \\
\hline Net Income Growth & $-970.60 \%$ & $-148.59 \%$ & $-26.49 \%$ & $3.60 \%$ & - \\
\hline Net Margin & $10.14 \%$ & - & - & - & - \\
\hline Net Income After Extraordinaries & $(5,717)$ & (534) & 1,099 & 1,495 & 1,443 \\
\hline Net Income Available to Common & $(5,717)$ & (534) & 1,099 & 1,495 & 1,443 \\
\hline EPS (Basic) & $(9.00)$ & $(0.84)$ & 1.71 & 2.31 & 2.21 \\
\hline EPS (Basic) Growth & $-973.98 \%$ & $-149.12 \%$ & $-26.03 \%$ & $4.39 \%$ & - \\
\hline Basic Shares Outstanding & 635 & 637 & 642 & 646 & 650 \\
\hline EPS (Diluted) & - & $(0.84)$ & 1.71 & 2.31 & 2.21 \\
\hline EPS (Diluted) Growth & $0.00 \%$ & $-149.12 \%$ & $-26.03 \%$ & $4.24 \%$ & . \\
\hline
\end{tabular}

The data in the chart could give us a clear view on how the Delta airline get effected from the covid-19 company. Through comparing the 2020 data with the same quarter but in 2019. It shows that from the profit and loss account, the sales growth decreased $83 \%$ than the same period of 2019, which shows the effect of covid-19 to the delta airlines entirely. Moreover, the gross profit of 30-June-2019 is 3,060 million dollars, while the gross profit of the same quarter this year is negative 3,332 million dollars. The decreasing rate is $-1471.19 \%$. The net income growth is also huge by decreasing $970 \%$. All the data from the income statement show the huge decreasing of income and revenue, with increased spending. Table 2 is the balance sheet of Delta airlines, which shows the value of an organization's assets and liabilities at a point in time. 
TABLE 2. BALANCE SHEET OF DELTA AIRLINES

\begin{tabular}{|c|c|c|c|c|c|}
\hline \multicolumn{6}{|l|}{ Assets } \\
\hline Fiscal year is January-December. All values USD Millions. & 30-Jun-2020 & 31-Mar-2020 & 31-Dec-2019 & 30-Sep-2019 & 30-Jun-2019 \\
\hline Cash \& Short Term Investments & 15,781 & 6,006 & 3,094 & 1,945 & 2,136 \\
\hline Cash Only & 11,479 & 6,006 & 3,094 & 1,945 & 2,136 \\
\hline Cash \& Short Term Investments Growth & $162.75 \%$ & $94.12 \%$ & $59.07 \%$ & $-8.94 \%$ & - \\
\hline Cash \& ST Investments / Total Assets & $21.84 \%$ & $8.74 \%$ & $4.79 \%$ & $3.08 \%$ & $3.42 \%$ \\
\hline Total Accounts Receivable & 1,375 & 2,280 & 2,854 & 2,836 & 2,844 \\
\hline Accounts Receivables, Net & 1,375 & 2,280 & 2,854 & 2,836 & 2,844 \\
\hline Accounts Receivables, Gross & 1,496 & 2,296 & 2,867 & 2,850 & 2,858 \\
\hline Bad Debt/Doubtful Accounts & (121) & (16) & (13) & (14) & (14) \\
\hline Accounts Receivable Growth & $-39.69 \%$ & $-20.11 \%$ & $0.63 \%$ & $-0.28 \%$ & - \\
\hline Accounts Receivable Turnover & 1.07 & 3.77 & 4.01 & 4.43 & 4.41 \\
\hline Inventories & 847 & 974 & 1,251 & 1,072 & 1,083 \\
\hline Raw Materials & 847 & 974 & 1,251 & 1,072 & 1,083 \\
\hline Other Current Assets & 912 & 1,015 & 1,050 & 1,091 & 1,071 \\
\hline Miscellaneous Current Assets & 912 & 1,015 & 1,050 & 1,091 & 1,071 \\
\hline Total Current Assets & 18,915 & 10,275 & 8,249 & 6,944 & 7,134 \\
\hline \multicolumn{6}{|l|}{ Liabilities \& Shareholders' Equity } \\
\hline All values USD Millions. & 30-Jun-2020 & 31-Mar-2020 & 31-Dec-2019 & 30-Sep-2019 & 30-Jun-2019 \\
\hline ST Debt \& Current Portion LT Debt & 5,962 & 5,105 & 3,088 & 3,040 & 3,122 \\
\hline Short Term Debt & - & 768 & 801 & 844 & 841 \\
\hline Current Portion of Long Term Debt & 5,230 & 4,337 & 2,287 & 2,196 & 2,281 \\
\hline Accounts Payable & 2,332 & 3,337 & 3,266 & 3,470 & 3,359 \\
\hline Accounts Payable Growth & $-30.12 \%$ & $2.17 \%$ & $-5.88 \%$ & $3.30 \%$ & - \\
\hline Other Current Liabilities & 11,856 & 10,950 & 13,850 & 13,701 & 14,683 \\
\hline Accrued Payroll & 1,809 & 1,844 & 3,701 & 3,119 & 2,617 \\
\hline Miscellaneous Current Liabilities & 10,047 & 9,106 & 10,149 & 10,582 & 12,066 \\
\hline Total Current Liabilities & 20,150 & 19,392 & 20,204 & 20,211 & 21,164 \\
\hline Current Ratio & 0.94 & 0.53 & 0.41 & 0.34 & 0.34 \\
\hline Quick Ratio & 0.90 & 0.48 & 0.35 & 0.29 & 0.29 \\
\hline Cash Ratio & 0.78 & 0.31 & 0.15 & 0.10 & 0.10 \\
\hline Long-Term Debt & 24,783 & 17,866 & 14,167 & 13,364 & 13,249 \\
\hline Long-Term Debt excl. Capitalized Leases & 19,412 & 12,662 & 8,052 & 7,923 & 7,710 \\
\hline Capitalized Lease Obligations & - & - & 821 & - & - \\
\hline
\end{tabular}

The total asset of delta have increased 5\% due to the increase of cash and short term investments. However, when it comes to liability, the recent liability increased $88 \%$. Although the assets have grown, the liability have increased much more than it [1].

\subsection{Ratio Analysis}

The further final account analysis could involve ratio analysis. The ratio analysis is seldom based on the data shown in the final account. We can know the changes at the first sight [3].

One of the profitability ratio expresses the profits as a percentage of sales revenue [4].

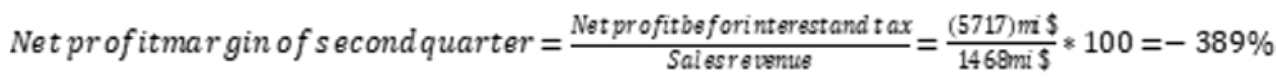

$$
\begin{aligned}
& \text { Net prof itmar gin of first quarter }=\frac{(534) \mathrm{mi} \mathrm{s}}{8592 \mathrm{mis}} * 100=-6.22 \%
\end{aligned}
$$


The NPM of second quarter implied that the negative financial had returned into this kind of situation, and which lacks of efficiency that will manage the expenses of Delta. Managing less seats and well disinfection measures will both add the expenses of Delta. It is known that the normal expenses for initial fuel and air-plane care are expensive, and these basic expenses are the life of an air company, even the expenses far from profit. If they get nothing profit from the loss, it can lead to the negative NPM. The first quarter was compared with the old one, which is the beginning of epidemic corona virus as no airline policies have been made for it, that is why the NPM shows great disparity which may be caused by the seating policy. In order to improve the NPM, the company needs to reduce daily expenses like plane care, gasoline fee and other unnecessary payment, which can make up for the damage of sudden power completion.

Current ratio belongs to the liquidity ratio and it calculates the values of a firm's liquid assets compared to its short-term liabilities [4].

$$
\begin{aligned}
& \text { Currentratio of first quarter }=\frac{\text { current as sets }}{\text { current liabilities }}=\frac{18915 \mathrm{mi}}{20150 \mathrm{mi}}=0.92 \\
& \text { Currentratio of second quarter }=\frac{10275 \mathrm{mi}}{19392 \mathrm{mi}}=0.52
\end{aligned}
$$

As can be seen above, for all the quarters, the current liabilities even exceed the current assets obviously. The second quarter current ratio shows a recovery from the first quarter. This means the Delta is taking an action to manage its current accounts and showing improvement, indicating that blocking the seats did not give much burden or depression on accounts, which is a good news that we still have time to take action on this emergency epidemic. Delta could afford the series of CSR action in the later months.

Efficiency ratios are always used to measure how an organization takes advantage of its resources and available capital to generate income [4].

$$
\begin{aligned}
& \text { Creditor daysof second quarter: } \frac{\text { Creditors }}{\text { Costof goods sold }} * 365=\frac{5962}{4800} * 365= \\
& 453.4 \text { daysCreditor days of first quarter }: \frac{\text { Creditors }}{\text { Cost of goods sold }} * 365=\frac{5105}{8349} * 365=223 \text {. 2d ays }
\end{aligned}
$$

The creditor days rises in the second quarter when comparing with the first quarter. Delta might have cash flow problem, the result of negotiation with its suppliers might helping them to generate more current assets. Thus, from this ratio, it can be seen that blocking the middle seat does bring effects, but Delta may have already taken actions in order to fulfill it.

\subsection{Force field analysis}

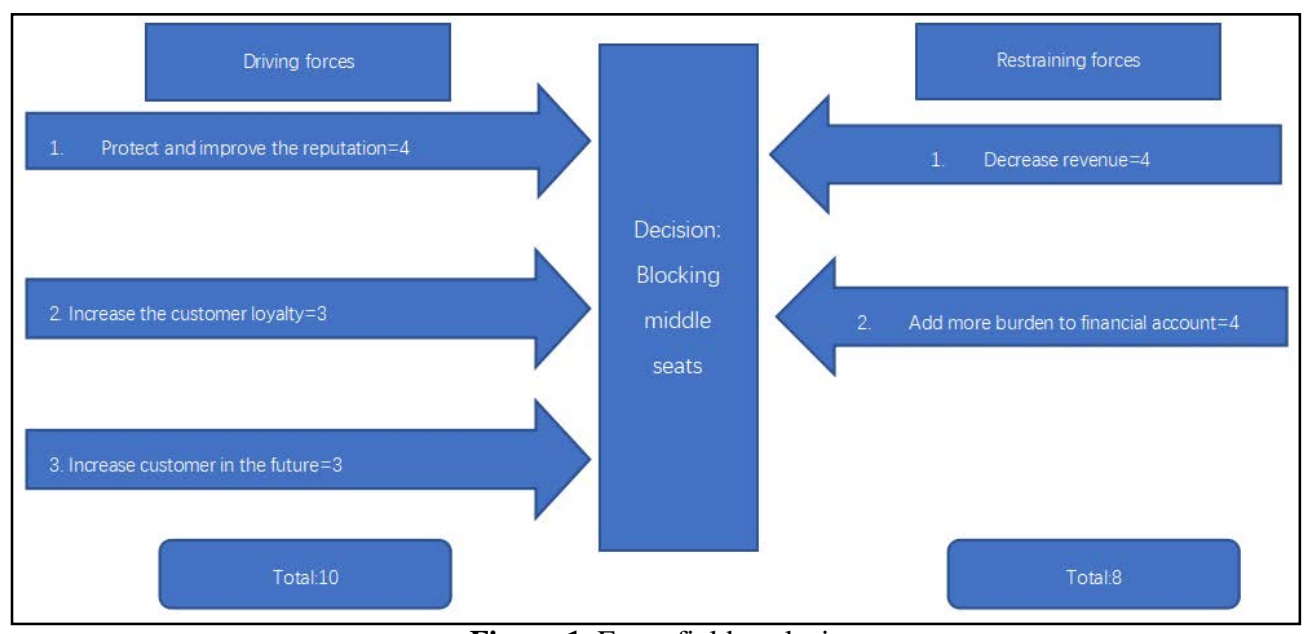

Figure 1. Force field analysis

Limiting the number of passengers shows the consideration of social security and ethics. Everyone can know and can feel if they really take this air-plane. This kind of social security not only displays it by mouths but also in action. Delta is constructing a corporate social responsibility through this decision. The mass social media could make it easier for general public around the world to know the ethical business behavior. The good corporate image with customers and corporate reputation with the government enable the Delta to gain competitive advantages. This kind of profit comes without expecting, because our initial thoughts just want to solve the problems that epidemic brought. Therefore, CSR also brings profit to the company especially. Overall, the author gives the driving factors 10 points. At the same time, the restrain forces are the profit, and CSR may not 
raise it in the short-term. It not only brings the cost but also decreases the profit currently. But in the long-term, the revenue is going be increased after the pandemic. However, in the current situation, the covid-19 is really a big hit for the airline company. In addition, the policy limited any industries taking this chances to earn revenue, which is contradicted to the objective of business-to gain profit. The point that restraining force get is 8 points. Something can be learned from the results, and the decision may bring more benefits to the business more than its drawbacks.

\section{Conclusion}

As can be seen above based on the analysis, the policy blocking the middle seats could be regarded as corporate social responsibilities, especially in this hard time. However, it is same for others companies, because they have to think of the good approaches to solve the problems in this hard time. For example, other competitors like the United airlines, they are also keeping seeking revenue recovery at the beginning of the epidemic. But they finally lost in that they overlooked the importance of passenger security and social responsibilities, which are the key points to solve this problems. That is why they can not solve it well like Delta. Delta is outstanding as they achieves its reputation and good corporate picture so well. It can be inferred that Delta Air Lines will gain competitive advantages and make profits soon as long as they persist this policy. Considering the current situation, the action may decrease the profit and increase the expenses, which cannot be covered as before. This result is unavoidable, which is not only because of decreasing middle blocking seat policy. In a word, Delta Air Lines may need a few years to recover after getting damage from the pandemic; but in this process they can really gain a lot. Lastly, through the analysis, we can know that Delta Air Lines should carry on the blocking seat policy because it did not add any burden on the Delta account. However, the research was influenced by other factors that the airline industry has to face. The financial account can not be accurate enough to indicate these affecting problems by the blocking seats policy. The further research should be conducted about the ways that Delta airlines can cover its loss.

\section{ACKNOWLEDGMENT}

Thanks for all the professors and teachers who have helped me and supported me. Their fantastic teaching gives me the inspiration to conduct the research. Also, thanks for my family who are always encourage me to keep on finishing this paper.

\section{REFERENCES}

1. Journal, Wall Street. "DAL | Delta Air Lines Inc. Quarterly Balance Sheet - WSJ.” The Wall Street Journal, Dow Jones \& Company, [Online] Available:
www.wsj.com/market-data/quotes/DAL/financials/q uarter/balance-sheet. [Assessed on 30/8/2020]

2. Schaper, David. “Coronavirus Costs Delta Air Lines Nearly \$6 Billion In 2nd Quarter.” NPR, NPR, 14 July, 2020, [Online] Available: www.npr.org/sections/coronavirus-live-updates/202 0/07/14/891145938/coronavirus-costs-delta-airlinesnearly-6-billion-in-second-quarter. [Assessed on 30/8/2020]

3. Slotnick, David. “'Delta May Be onto Something': Experts Describe How the Company Is Winning with Customers Even Though Rival Airlines Can Fit More Passengers." Business Insider, Business Insider, 5 Aug. 2020, [Online] Available: www.businessinsider.com/airlines-middle-seat-socia l-distance-coronavirus-delta-2020-8. [Assessed on 30/8/2020]

4. HOANG, PAUL. BUSINESS MANAGEMENT 4TH EDITION. IBID Press, 2018. [Assessed on $1 / 9 / 2020]$

5. “Safer Travel.” Coronavirus Travel: FAQs | Delta Air Lines, www.delta.com/us/en/travel-update-center/coronavir us-travel-faqs. [Assessed on 1/9/2020] 